\title{
Evaluation of Signal/Cut-off Ratio by Anti-hepatitis Delta Virus Enzyme Immunoassay Method in the Diagnosis of Hepatitis Delta Virus Infection
}

\author{
Hepatit Delta Virüs Enfeksiyonunun Tanısında Anti-Hepatit Delta Virüs Enzim \\ Immünoassay Yöntemi ile Sinyal/Cut-off Oranının Değerlendirilmesi
}

\author{
๑ Ayfer Bakır, ๑ Nuran Karabulut, @ Sema Alaçam, ๑ Murat Yaman, @ Mustafa Önel, ๑ Ali Ağaçfidan
}

Istanbul University, Istanbul Faculty of Medicine, Department of Medical Microbiology, Division of Virology and Fundamental Immunology, Istanbul, Turkey

\begin{abstract}
Objectives: The hepatitis delta virus (HDV) is an enveloped, negative-sense, single-stranded RNA virus in the genus Deltavirus. In this study, it was aimed to evaluate the ratio of anti-HDV signal/ cut-off $(\mathrm{S} / \mathrm{CO})$ in the diagnosis of HDV infection in patients who were positive for anti-HDV.

Materials and Methods: Between August 2014 and December 2018, 156 patients, who were detected hepatitis B surface antigen (HBsAg) and anti-HDV positivity and were analyzed HDV-RNA, were included in the study. Anti-HDV antibody and HBsAg tests were analyzed by micro-ELISA method in serum samples and HDV-RNA was studied by real-time polymerase chain reaction method in plasma samples.

Results: HDV-RNA was detected in $42.9 \%$ (67/156) of the anti-HDV positive patients. The mean S/CO value of anti-HDV in HDV-RNA positive group $(8.99 \pm 3.53)$ was significantly higher than HDV-RNA negative group $(5.99 \pm 3.73)(p<0.001)$. When the $S / C O$ value was determined as 6.13 by receiver operating characteristic (ROC) analysis; sensitivity, specificity, positive, and negative predictive values were $79.8 \%, 59.7 \%, 72.4 \%$, and $68.9 \%$, respectively. Conclusion: In this study, the optimal cut-off value which provides the maximum sum of sensitivity and specificity for the test was found 6.13 by $R O C$ analysis. The reporting with the S/CO ratio of anti-HDV ELISA results and determining each laboratory's optimal cut-off value may be helpful for the diagnosis of HDV infection.

Keywords: HDV, HDV infection, ROC analysis
\end{abstract}

ÖZ

Amaç: Hepatit delta virüsü (HDV), Deltavirus genusunda, zarfll, negatif polariteli, tek iplikli bir RNA virüsüdür. Bu çalışmada, anti-HDV pozitif olan hastalarda HDV enfeksiyonu tanısında anti-HDV sinyal/ cut-off (S/CO) oranının değerlendirilmesi amaçlandı.

Gereç ve Yöntemler: Ağustos 2014-Aralık 2018 tarihleri arasında hepatit B yüzey antijeni (HBsAg) ve anti-HDV pozitif saptanan ve HDV-RNA testi çalışımış toplam 156 hasta çalışmaya dahil edildi. Anti-HDV antikoru ve HBsAg testleri serum örneklerinde mikroELISA yöntemi ile, HDV-RNA testi ise plazma örneklerinde real-time polimeraz zincir reaksiyonu yöntemi ile çalışıldı.

Bulgular: Anti-HDV pozitif hastaların \%42,9'unda (67/156) HDVRNA saptandı. HDV-RNA pozitif grubun anti-HDV S/CO ortalaması $(8,99 \pm 3,53)$, HDV-RNA negatif gruba $(5,99 \pm 3,73)$ göre anlamlı olarak yüksek saptandı $(p<0,001)$. Alıcı işletim karakteristiği $(R O C)$ analizi ile S/CO değeri 6,13 belirlendiğinde; duyarlılık, özgüllük, pozitif ve negatif prediktif değerler sırasıyla \%79,8, \%59,7, \%72,4 ve \%68,9 idi.

Sonuç: Bu çalışmada, ROC analizi ile test için maksimum duyarlıık ve özgüllük toplamını sağlayan optimal cut-off değeri 6,13 bulundu. Anti-HDV ELISA sonuçlarının S/CO oranı ile bildirilmesi ve her laboratuvarın optimal cut-off değerini belirlemesi, HDV enfeksiyonu tanısında yol gösterici olabilir.

Anahtar Kelimeler: HDV, HDV enfeksiyonu, ROC analizi

Bakır A, Karabulut N, Alaçam S, Yaman M, Önel M, Ağaçfidan A. Evaluation of Signal/Cut-off Ratio by Anti-hepatitis Delta Virus Enzyme Immunoassay Method in the Diagnosis of Hepatitis Delta Virus Infection. Viral Hepat J. 2019;25:97-100. 


\section{Introduction}

The hepatitis delta virus (HDV), which is the only member of the only species in the genus Deltavirus, is an enveloped, negative-sense, single-stranded RNA virus $(1,2)$. HDV requires the simultaneous presence of hepatitis $B$ virus (HBV) to complete its life cycle (3). Although HDV suppresses HBV replication, it causes variable clinical presentation ranging from mild disease to fulminant liver failure (4). It is estimated that 18 million hepatitis B surface antigen (HBsAg) carriers in the world also have anti-HDV antibodies, which is $5 \%$ of $\mathrm{HBV}$-infected individuals (5). The Amazon region of South America, the Middle East, the Mediterranean region, West and Central Africa are highly endemic areas for HDV (6). Turkey is considered a moderate endemic area for HDV infection with regional differences $(7,8)$. HDV can cause co-infection with HBV or superinfection in people infected with HBV (9). Diagnosis of coinfection or superinfection with HDV is based on serological and molecular methods. The diagnosis of acute HDV co-infection is based on the detection of HDV-Ag, HDV-RNA and anti-HDV antibodies, together with markers of HBV infection. HBV-DNA, an indicator of HBV replication, could be suppressed during acute HDV infection and could not be detected $(10,11)$. Therefore, all HBsAg positive patients should be analyzed anti-HDV antibody testing and especially should be recommended in case of acute hepatic exacerbation (10). The diagnosis of chronic HDV infection is determined by the absence of immunoglobulin $\mathrm{M}(\mathrm{lgM})$ antibody against hepatitis $B$ core antigen and the presence of HBV and HDV infection markers. HDV-RNA is the gold standard method for the diagnosis of HDV infection due to sensitivity and specificity problems in HDV-Ag tests (11).

The first step in the diagnosis of HDV is anti-HDV antibody screening against HDV-Ag in individuals with positive HBsAg (9). Although the sensitivity of ELISA tests is high, populations with low prevalence have lower positive predictive values and higher false positivity rates. The aim of this study was to evaluate the antiHDV signal/cut-off (S/CO) ratio in the diagnosis of HDV infection in patients with anti-HDV positivity.

\section{Materials and Methods}

\section{Study Group}

This retrospective study included 156 patients, who were detected HBsAg and anti-HDV positivity and were analyzed HDVRNA, between August 2014 and December 2018. Ethical approval for this study was obtained by the Ethics Committee of Istanbul University Faculty of Medicine (approval number: 2018/1766/84).

\section{Serological Analysis}

Anti-HDV and HBsAg tests in serum samples were performed on Triturus Enzyme Immunoassay Analyzer (Grifols, Spain) using micro-enzyme immunoassay (ELISA) kits (Dia. Pro, Diagnostic Bioprobes, Milano, Italy). The cut-off value was calculated according to the manufacturer's recommendations. Test results were calculated by proportioning the sample absorbance to the cutoff value. If $S / C O$ ratios are $\geq 1.00$, the result of the test is evaluated as positive.

\section{Molecular Analysis}

Between August 2014 and October 2016, HDV-RNA extraction was performed using the High Pure Viral Nucleic Acid kit (Roche Applied Science, Basel, Switzerland) in plasma samples. The RNA molecule was transformed into complementary DNA (cDNA) using the Transcriptor First Strand cDNA Synthesis V6 kit (Roche Diagnostics, Mannheim, Germany). The cDNA was amplified by the LightCycler 2.0 instrument (Roche Diagnostics $\mathrm{GmbH}$, Switzerland) using a polymerase chain reaction (PCR) mixture prepared with the TIB Molbiol HDV GmbH kit (Berlin, Germany) and the Light Cycler FastStart Master HybProbe kit (Roche Diagnostics, Germany). Between October 2016 and December 2018, HDVRNA was obtained using the Qiagen EZ1 virus mini kit V2 nucleic acid extraction kit (Qiagen, Germany). Reverse transcription and amplification of RNA molecules was performed using a PCR mixture prepared with Fluorion HDV ONP 1.0 Real-Time PCR Kit (lontek, Istanbul, Turkey) by Rotor-Gene $\mathrm{Q}$ instrument (Qiagen, Germany).

\section{Statistical Analysis}

Data analysis was performed using SPSS 25 (SPSS Inc, Chicago, IL, USA) program. The suitability of the variables to normal distribution was examined by visual methods (histogram and probability graphs) and Kolmogorov-Smirnov test. Variables were compared using Student's t-test or Mann-Whitney $U$ test. Pearson chi-square or Fisher exact tests were used for qualitative variables. Sensitivity, specificity, negative predictive and positive predictive values were investigated by determining the significant cut-off values of the test by receiver operating characteristic (ROC) curve analysis. $\mathrm{P}$ value of less than 0.05 was considered statistically significant.

\section{Results}

Of the 156 anti-HDV positive patients with a mean age of $48.89 \pm 11.65$ years (range: $19-90$ years), $49.4 \%$ were male and $50.6 \%$ were female. The mean age of the male and female patients was $47.74 \pm 11.93$ and $50.01 \pm 11.34$, respectively $(p=0.22)$. HDV-RNA positivity was detected in $42.9 \%$ (67/156) of anti-HDV positive patients.

The mean age of the viremic patients was $49.66 \pm 10.20$ and the mean age of the non-viremic patients was $48.31 \pm 12.67$ $(p=0.48)$. The mean $\mathrm{S} / \mathrm{CO}$ of anti-HDV positive patients was 7.70 3.90 (1.18-19.1). The mean S/CO value of anti-HDV in HDVRNA positive group $(8.99 \pm 3.53)$ was significantly higher than HDVRNA negative group $(5.99 \pm 3.73)(p<0.001)$ (Figure 1). A total of 67 $(45.9 \%)$ samples with $\mathrm{S} / \mathrm{CO} \geq 1$ by the Dia. Pro anti-HDV assay was false-positive.

When the S/CO value was 6.13 by ROC analysis, a total of 27 (27.6\%) samples with S/CO $\geq 6.13$ was false-positive. When S/CO $\geq 6.13$, the sensitivity, specificity, positive and negative predictive values were $79.8 \%, 59.7 \%, 72.4 \%$ and $68.9 \%$, respectively. A total of $24(28.2 \%)$ samples with $\mathrm{S} / \mathrm{CO} \geq 7.15$ was false-positive. When $\mathrm{S} / \mathrm{CO} \geq 7.15$, sensitivity, specificity, positive and negative predictive values were $68.5 \%, 64.2 \%, 71.8 \%$ and $60.6 \%$, respectively. The area under the curve (AUC) was 0.72 (95\% Cl: 0.64-0.80), $p<0.001$ (Figure 2). The performance results of the Dia. Pro anti-HDV test kit at different S/CO values are presented in Table 1. 


\section{Discussion}

The first approach in the diagnosis of HDV infection is to investigate the antibodies against HDV-Ag in HBsAg-positive individuals. Anti-HDV antibody can be detected in immunocompetent patients with HDV infection (10). While anti-HDV immunoglobulin G (lgG) antibodies are detected in individuals with HDV infection even after clearance of the virus, anti-HDV IgM antibodies can

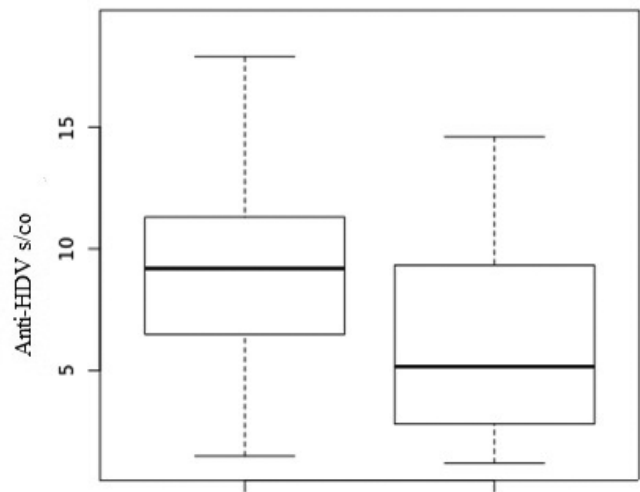

HDV-RNA positive HDV-RNA negative

Figure 1. Anti-HDV S/CO ratios in HDV-RNA negative and positive group HDV: Hepatitis delta virus, S/CO: Signal/cut-off

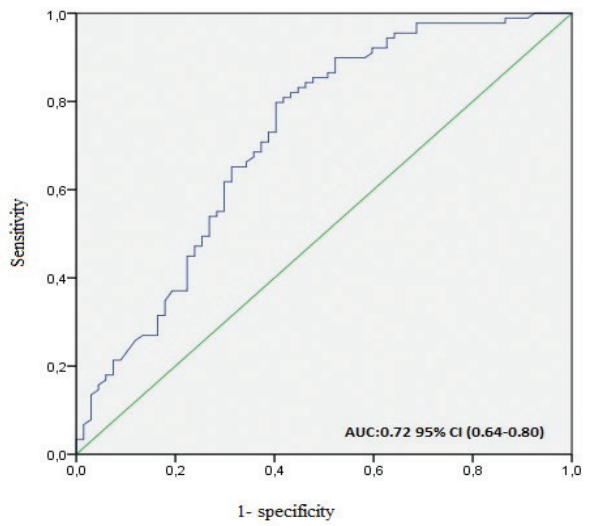

Figure 2. The receiver-operating characteristic curve of anti-HDV S/CO ratio for predicting HDV viremia

HDV: Hepatitis delta virus, S/CO: Signal/cut-off, AUC: Area under the curve, $\mathrm{Cl}$ : Confidence interval be detected as a serological marker of HDV replication in the majority of patients with acute infection (12). Although anti-HDV IgM antibodies are indicative of acute HDV infection, anti-HDV IgM antibody tests may not be able to detect low antibody titers. Commercial anti-HDV antibody ELISA kits detected both IgM and lgG are preferred for HDV screening in HBsAg positive patients $(13,14)$. However, HDV-RNA is the only reliable parameter of HDV replication.

In this study, HDV-specific total antibodies were investigated and reported semi-quantitatively by determining the $\mathrm{S} / \mathrm{CO}$ ratio. The mean S/CO of anti-HDV in HDV-RNA positive group (8.99 \pm 3.53$)$ was significantly higher than HDV-RNA negative group $(5.99 \pm 3.73)$ $(p<0.001)$. The results were consistent with rare studies on this subject (15). In a cross-sectional study performed using the anti-HDV radio-immunoassay kit (Abbott Laboratories, Chicago, IL, USA), it was demonstrated that high anti-HDV titers were correlated with HDV viremia (16).

Although studies on prediction of viremia of ELISA S/CO ratio have been performed mostly with the hepatitis $\mathrm{C}$ virus (HCV), such studies for HDV are quite limited. Anti-HCV S/CO ratios for prediction of HCV viremia in different studies, differences have shown depending on the size of the sample, HCV prevalence in the studied population, and kit differences (17).

It is of interest to define the best S/CO cutoff before using anti-HDV tests in the clinical routine. Thus, it could be decreased false-positive results. S/CO can vary across kits, and populations with different HDV infection rates. When $\mathrm{S} / \mathrm{CO} \geq 1$ by the recommendation of the manufactory, $45.9 \%$ of samples had false-positive by the Dia. Pro anti-HDV assay. When $\mathrm{S} / \mathrm{CO} \geq 6.13$, false-positivity decreased to $27.6 \%$. In the present study, it was observed that the false-positive ratio decreased when the S/CO ratio increased.

In a study performed with the anti-HDV antibody ELISA kit (Hepanostika HDV, Organon Teknika, the Netherlands) in Turkey; when the ELISA index value was 100.10, sensitivity, specificity, negative and positive predictive values were 93\%, 80\%, 93\%, $76 \%$ respectively. The AUC was found to be 0.934 (15). In this study, the optimal cut-off value which provides a total of the maximum sensitivity and specificity for the test was found 6.13. The AUC was found 0.72 (95\% Cl: $0.64-0.80), p<0.001$ by ROC curve analysis. Results below the optimal cut-off value should be retested with HDV-RNA and another anti-HDV kit. Determination

Table 1. Performance of the Dia. Pro anti-HDV assay according to S/CO ratios

\begin{tabular}{|c|c|c|c|}
\hline & \multicolumn{3}{|l|}{$\mathrm{S} / \mathrm{CO}^{\S}$} \\
\hline Number of samples & 146 & 98 & 85 \\
\hline True positive rates & $89(54.1 \%)$ & $71(72.4 \%)$ & $61(71.8 \%)$ \\
\hline Sensitivity & $*$ & $79.8 \%(69.9 \%-87.6 \%)$ & $68.5 \%(57.8 \%-78.0 \%)$ \\
\hline Positive predictive value & $*$ & $72.4 \%(65.9 \%-78.2 \%)$ & $71.8 \%(64.2 \%-78.3 \%)$ \\
\hline Negative predictive value & * & $68.9 \%(58.5 \%-77.8 \%)$ & $60.6 \%(51.9 \%-68.7 \%)$ \\
\hline
\end{tabular}


of cut-off index value in test kits could be clinically important for predicting true HDV viremia.

\section{Conclusion}

This study showed that Dia. Pro anti-HDV antibody test kit had a good clinical performance for anti-HDV S/CO value of 6.13. The $\mathrm{S} / \mathrm{CO}$ ratio in the HDV test could be used in the clinical decisionmaking process if it can correctly predict the diagnosis of HDV before HDV-RNA is analyzed. In addition to anti-HDV ELISA results, reporting of S/CO ratio and determining each laboratory's optimal cut-off value may be helpful for the diagnosis of HDV infection.

\section{Ethics}

Ethics Committee Approval: Ethical approval for this study was obtained by the Ethics Committee of Istanbul University Faculty of Medicine (approval number: 2018/1766/84).

Informed Consent: Retrospective study.

Peer-review: Externally and internally peer-reviewed.

\section{Authorship Contributions}

Concept: A.B., A.A., Design: A.B., A.A., Data Collection or Processing: A.B., N.K., S.A., M.Y., M.Ö., Analysis or Interpretation: A.B., N.K., S.A., Literature Search: A.B., M.Y.

Conflict of Interest: No conflict of interest is declared by the authors.

Financial Disclosure: The authors declared that this study received no financial support.

\section{References}

1. Rizzetto M. The adventure of delta. Liver Int. 2016;36:135-140.

2. ICTV. 9th Report (2011). Virus Taxonomy: 2017 Release. Deltavirus [08.06.2019]. Available from:https://talk.ictvonline.org/ ictv-reports/ictv_9th_report/negative-senserna-viruses-2011/w/ negrna_viruses/211/deltavirus

3. Negro F. Hepatitis D virus coinfection and superinfection. Cold Spring Harb Perspect Med. 2014;4:a021550.

4. Hughes SA, Wedemeyer $\mathrm{H}$, Harrison PM. Hepatitis delta virus. Lancet. 2011;378:73-85.

5. Scarponi CFO, Silva RDND, Souza Filho JA, Guerra MRL, Pedrosa MAF, Mol MPG. Hepatitis delta prevalence in South America: A systematic review and meta-analysis. Rev Soc Bras Med Trop. 2019;52:e20180289.

6. Butler EK, Rodgers MA, Coller KE, Barnaby D, Krilich E, Olivo A, Cassidy M, Mbanya D, Kaptue L, Ndembi N, Cloherty G.
High prevalence of hepatitis delta virus in Cameroon. Sci Rep. 2018;8:11617.

7. Kemal Celen M, Tekin Koruk S, Aygen B, Dal T, Karabay O, Tosun S, Koksal I, Turgut H, Onlen Y, Balik I, Yildirim N, Sinan Dal M, Ayaz C, Tabak F. The characteristics of patients with chronic hepatitis B in Turkey. Med Glas (Zenica). 2014;11:94-98.

8. Özkan H. Epidemiology of chronic hepatitis B in Turkey. Euroasian J Hepatogastroenterol. 2018;8:73-74.

9. Botelho-Souza LF, Vasconcelos MPA, Dos Santos AO, Salcedo JMV, Vieira DS. Hepatitis delta: Virological and clinical aspects. Virol J. 2017;14:177.

10. Yurdaydın C, Tabak F, Kaymakoğlu S, Akarsu M, Akıncı EG, Akkız H, Alkım C, Çekin AH, Çuvalcı NÖ, Demir K, Değertekin B, Dökmetaş I, Ersöz G, Hizel K, Kandemir FÖ, Önlen Y, Sonsuz A, Senateş E, Tosun S, Tözün N, Idilman R, Guidelines Study Group $\mathrm{VH}$. Diagnosis, management and treatment of hepatitis delta virus infection: Turkey 2017 Clinical Practice Guidelines. Turk J Gastroenterol. 2017;28:84-89.

11. Kamili S, Drobeniuc J, Mixson-Hayden T, Kodani M. Delta hepatitis: Toward improved diagnostics. Hepatology. 2017;66:1716-1718.

12. Brichler S, Le Gal F, Butt A, Chevret S, Gordien E. Commercial real-time reverse transcriptase PCR assays can underestimate or fail to quantify hepatitis delta virus viremia. Clin Gastroenterol Hepatol. 2013;11:734-740.

13. Brichler S, Le Gal F, Neri-Pinto F, Mansour W, Roulot D, Laperche S, Gordien E. Serological and molecular diagnosis of hepatitis delta virus infection: Results of a French national quality control study. J Clin Microbiol. 2014;52:1694-1697.

14. Mederacke I, Yurdaydin C, Dalekos GN, Bremer B, Erhardt A, Cakaloglu Y, Yalcin K, Gurel S, Zeuzem S, Zachou K, Bozkaya H, Dienes HP, Manns MP, Wedemeyer H; Hep-Net/International Delta Hepatitis Study Group. Anti-HDV immunoglobulin M testing in hepatitis delta revisited: correlations with disease activity and response to pegylated interferon- $\alpha 2 a$ treatment. Antivir Ther. 2012;17:305-312.

15. Caymaz SO, Sayıner AA, Özkütük AA, Abacıoğlu YH. Anti-HDV enzyme immunoassay index in predicting HDV viremia in serum samples. Turk J Med Sci 2013;43:294-298.

16. Huang YH, Wu JC, Sheng WY, Huo TI, Chang FY, Lee SD. Diagnostic value of anti- hepatitis D virus (HDV) antibodies revisited: a study of total and IgM anti-HDV compared with detection of HDVRNA by polymerase chain reaction. J Gastroenterol Hepatol. 1998;13:57-61.

17. Ranjbar Kermani F, Sharifi Z, Ferdowsian F, Paz Z, Tavassoli F. The usefulness of anti-HCV signal to cut-off ratio in predicting viremia in anti-HCV in patients with hepatitis $\mathrm{C}$ virus infection. Jundishapur J Microbiol. 2015;8:e17841. 